\title{
How Helpdesk Agents Help Clients
}

\author{
Michaël Steehouder \\ University of Twente \\ M.F.Steehouder@Utwente.nl
}

\begin{abstract}
Helpdesks are an important channel for supporting users of technical products and software. This study analyses some phenomena in telephone helpdesk calls, using conversational analysis as a methodological and theoretical framework. Helpdesk calls are characterized by the common goal of the helpdesk agent and the client to understand and solve the client's problem with a particular technical device or with computer software. Both parties cooperate in a complex manner to define and diagnose the problem, and to solve it. The paper identifies the typical structure of a helpdesk call and describes a number of strategies that the participants use to make the call successful.
\end{abstract}

\section{Introduction}

Technical communication is usually defined as the art and science of 'translating' expert information for nonexperts, in particular users of technology. Traditionally, technical communicators create documents, on paper or on line, or they present technical information orally. Until now, there is little attention in the field for the special mode of technical communication that is practiced by technicians who work at customer contact centers or other telephone helpdesks. However, their number is estimated about 3 million in the United States only. Many support centers moved to East-Asian countries in the Nineties, but recently it seems that many companies return to the US again [1].

Although only a few studies about the effectiveness of helpdesk information have been published, statistics suggest that over half of the helpdesk calls does not result in a good solution for the client's problem [1]. This illustrates that the effectiveness of helpdesks is an important challenge for the field of technical and professional communication.

Customers often prefer helpdesks to other forms of support such as user guides, manuals, online help or webbased documentation for several reasons:
- Helpdesks release users from the burden of seeking the relevant information (which is often dispersed in written or electronic formats) themselves.

- When calling to a helpdesk, users can define their problems in their own words. They are not restricted to the technical terminology of the manufacturer which underlies the keywords in indexes and content lists.

- The helpdesk can give solutions for problems that are not discussed in the written documentation, e.g., problems of compatibility between different systems or devices.

- The helpdesk information can be tailored to the user; to his individual problems as well to his level of expertise.

- A helpdesk provides interactive help. The user can discuss the problem and the solution and the agent can act as a coach.

- The helpdesk is far more social than written documentation since it is an interpersonal form of support, even if both parties are anonym to each other.

Customer satisfaction about the service provided by a helpdesk depends on a variety of factors that are difficult to map. Of course, the quality of the solution is the most decisive factor, and supporting help agents with usable online help tools is an important step towards improvement of the helpdesk's quality [1]. It is for sure, however, that the experience of the conversation plays an important role too [2]. This justifies the practical relevance of studying conversational patterns in helpdesk calls.

\section{The global structure of a helpdesk call}

Several studies pay attention to the structure of helpdesk calls $[3,4,5,6,7]$. The following scheme seems to be typical for a helpdesk call $(\mathrm{A}=$ agent; $\mathrm{C}=$ client $)$.

\section{Opening phase}

- Identification of the participants+ greetings

- Introductory statement of A: "How can I help you?" 


\section{Problem analysis phase}

- Narrative exposition by C,

- optionally followed by an interrogation by $\mathrm{A}$

- optionally followed by a simulation of the problem by $\mathrm{A}$, guided by $\mathrm{C}$

Diagnosis phase

- Conclusion by A

- optionally followed by a discussion

Solution phase

- Announcement of the solution by A

- optionally followed by a discussion

Instruction phase

- Procedural instruction by A, executed by C

Evaluation phase

- Statement by $\mathrm{C}$ that the problem has been solved

\section{Closing phase}

- Thanking, goodbye

In the typical opening phase, the Agent identifies herself and opens the conversation with the characteristic question 'How can I help you?' Baker, Emmerson \& Firth argue that this question has two important functions. Firstly, it defines the goal of the conversation and the roles of both participants. Secondly, it invites the Client to start the problem description [7].

\section{Formulating the problem}

The problem analysis phase of helpdesk calls has been analyzed in detail by Baker, Emmison and Firth [6]. Fragment 1 illustrates the conventional way a client exposes his problem. The fragment originates from a call to an internal helpdesk of a non-profit organization.

\section{Fragment $1^{1}$}

$1 \mathrm{C} i \mathrm{k}$ heb het geweten, maar ik weet ik weet niet meer hoe ik het op moet lossen (.) I used to know it, but I don't know, don't know anymore how I should solve it

$2 \mathrm{C}$ ik heb mij namelijk mij in ik werk in excel I have namely myself I am working in excel

$3(0,5)$

4 A ja::? yes?

$5 \mathrm{C}$ en:: nou wil ik mijn cursor verplaatsen (.)en dat doe ik met de pijltoets $(1,0)$ and now I want to move my cursor and I do that with the arrow key

6 C maar dan gaat niet mijn (.) cursor weg maar dan gaat het blad opzij

\footnotetext{
${ }^{1}$ See appendix A for transcription codes. The English translations of the Dutch conversations are made to be close to the Dutch, and may therefore sound unusual for native English readers sometimes.
}

but then my cursor is not disappearing but the whole page is moving to one side

$7 \quad(5,5)$

$8 \mathrm{C}$ dat is een instelling denk ik een of andere instelling wat niet goed is

that's a setting I think some setting that's not right

$9 \mathrm{C}$ ik heb vanochtend het toetsenbord schoongemaakt en toen zal ik wel te vulluh, tuh tuh de toetsen aangeraakt hebben I cleaned the keyboard this morning and than I must have touched the keys

10 A: dat zou best eens kunnen that might well be the case

$11 \quad(3,0)$

12 A je werkt in excel zeg jij? you are working in excel you say?

This fragment starts with the client's justification for calling the help desk in line 1. Baker, Emmison \& Firth consider such justifications as important elements of the opening phase of help desk calls [6]. The justifications can take different forms, such as assertions that refer to the urgency of the problem, expressions of the caller's lack of expertise, or reports about attempts the caller has already done to solve the problem (including consulting other help sources).

After the justification, the real problem description starts. This takes usually the form of a narrative description of events. Baker, Emmison \& Firth suggest the following general scheme for this part of the conversation [5].

C [I'm working with product X]

A $[+/-$ yeah, okay $]$

$\mathrm{C}$ [and + the specific domain of $\mathrm{Y}]$

A $[+/-$ yeah, okay $]$

C [and/but]

$\mathrm{C}$ [something unwanted happened/happened]

A [ $+/-$ substantive comment or question] If no substantive comment or question:

$\mathrm{C}$ [elaboration, diagnosis, restatement of problem, etc.]

A [substantive comment or question]

The dialogue in Fragment 1 aligns with this general scheme. The client tells that he has a problem (line 1), specifies the product he is working with (line 2), and further specifies the specific domain. In this case - and many others - the domain specification takes the form of formulating a goal (move the cursor) and the action that was chosen to reach the goal (press the arrow key). Next, after a short pause, the problem is introduced by mentioning the reaction of the program, while the connective but indicates that the reaction is unexpected (and unwanted), and thus creates a problem. 
Differently from the general scheme, our agent does not use minimal acknowledgements such as yeah, or $o k a y$, to encourage the client to keep telling. Instead there is a long pause in line 7 , which apparently stimulates the client to elaborate on the possible cause of the problem in line 8 and 9. The cause mentioned in line 9 might seem unlikely at first glance, but it will turn out to be the true cause later.

The client's speculation about the cause is acknowledged by the agent in a rather non-committing way (dat zou best eens kunnen / that might well be the case). After another pause the agent continues with a question in line 12 , which starts the interrogation, the second element of the problem analysis.

A closer look at the client's narratives in our materials shows that there are two distinct forms. In many cases, the narrative takes the form of a 'historical report', a description of events that happened. Historical reports use the past tense, and go often with adverbial expressions of time. Fragment 2 shows a typical example of a report, with seemingly irrelevant details (line 4 and 7), and adverbial expressions of time (line 9). In line 11, the caller moves to a more or less scenario style of describing the problem, using the present tense, and formulating the problem in a more general way.

\section{Fragment 2}

$1 \mathrm{C}$ euh $(0,5)$ wij hebben hier een klein probleempje $\mathrm{e} h \mathrm{~h}$, we have a little problem here

2 A ja

$$
\text { yes }
$$

$3(0,8)$

$4 \mathrm{C}$ en wel eeeuh (.) we zijn gewoon aan het factureren that is uhh, we are just making an invoice

5 A hmhm

$6 \quad(0,5)$

$7 \mathrm{C}$ en op een of andere manier uh (.) zat dur iemand achter het toetsenbord die een beetje snel was and in some way, somebody was at the keyboard who was a bit too fast

8 A ja

yes

$9 \mathrm{C}$ op een gegeven moment is dat $(0,6)$ invoerveld (.) zeg maar dat normaal heb je boven de balk $(1,0)$ van uh uh $(1,3)$ zeg maar de hoofdbalk en daar onder komt dan zeg maar de het invoerveld van uh factureren

at a certain moment, the insertion field, you know that normally is above the bar of ehh, ehh, you know, the main bar, and beneath that is you know the insertion field of the invoices

$10 \mathrm{~A}$ ja yes

$11 \mathrm{C}$ en dat is een stukje omhoog geschoven zodat we onder een paar centimeter $(0,6)$ de achterkant van excel zien maar voor de rest (.) u::h $(0,8)$ niet maar durboven zijn dus die icoontjes allemaal weg $(0,2)$ dus je kunt zeg maar het veld $(0,6)$ factureren niet meer afsluiten

and that has moved up a bit, so that we can see the back side of excel some centimetres below, but above that all icons have disappeared, so you know you can't close the invoice window anymore.

Fragment 2 shows also a problem that is very manifest in many problem descriptions, namely that the caller has great difficulties in describing interface elements such as navigation bars, particular windows, etcetera. Future research into our materials might reveal deeper insight in the typical strategies that inexperienced users apply on referring to interfaces, program functions and other technical aspects of the software.

\section{Procedural instructions: coaching the client}

One of the most interesting parts of a helpdesk call is the instruction phase, where agents instruct clients to perform a number of actions in order to solve the problem. Agents assume that their clients are sitting in front of the computer, that the computer is on, and that the program is active. However, our collection of call transcriptions includes two examples of calls where this assumption was incorrect (the client was not at his computer, or the computer was off). In both cases, this was detected by the agent only after a period of time (in one case, only after 5 minutes!).

Fragment 3 illustrates the conventional way of giving instructions during telephone calls. It is taken from a call to the helpdesk of a provider of software for middle sized companies. The callers are usually administrators with an average expertise in using this software. The client in fragment 3 has a problem with the reference numbers of invoices that are created by the software. These numbers should be created automatically, but this does not work correctly from the beginning of the new fiscal year 2004. This is the reason for the call. After the problem analysis and diagnosis phases, the instruction phase starts, in which the agent directs the client to a dialogue box where a particular setting has to be changed.

\section{Fragment 3}

1 A oké mag u gaan naar menu (.) okay, you may go to menu

2 C $\quad$ $\uparrow \mathrm{j}[\mathrm{a}$ yes

3 A [inrichten administra $\uparrow$ tie $(0,7)$ organize administration 
$4 \mathrm{C}{ }^{\circ} \mathrm{menu}($.$) inrichten administratie { }^{\circ} \uparrow \mathrm{ja}$ menu organize administration yes

5 A financ $\uparrow$ ieel financial

6 C $\uparrow$ ja yes

7 A dagboeken $(1,4)$ joumals

$8 \mathrm{C}^{\text {odagboeken }}{ }^{\circ}$ joumals

9 A en dan ut u: $:$ h factuurverkoopboek $(1,8)$ and then invoice salesbook

$10 \mathrm{C}$ ofactuur uh v(h)erkoopboek (.) $\mathrm{ja}^{\circ}$ invoice salesbook yes

11 A mag u wijzigen doen may you do change

$12 \mathrm{C}{ }^{\circ}$ wijzigen $^{\circ}(.) \uparrow \mathrm{ja}$ change yes

13 A en dan ziet $u$ een aantal tabbladen en het derde is 't nummer:

and then you see a number of tab pages and the third is the number

14 A daar mag u op $\uparrow$ klikken

$15 \mathrm{C} \uparrow \mathrm{ja}$ you may click on that

16 A dan zult $u$ zien dat boekingen 2004 op vier nul nul nul een $\uparrow$ staat

than you will see that entry 2004 counts four zero zero zero

$17 \mathrm{C} \uparrow \mathrm{ja}$

yes

18 A daar mag u op $\uparrow$ klikken: you may click on that

$19 \mathrm{C} \uparrow \mathrm{ja}$ yes

$20 \mathrm{~A}$ en dan kiezen voor wijzi $\uparrow$ gen

$21 \mathrm{C} \uparrow \mathrm{ja}$ and than choose for change

yes

$22 \mathrm{~A}$ en daar mag $\mathrm{u}$ het gewenste nummer inzet $\downarrow$ ten $(0,5)$ and there you may put in the desired number

$23 \mathrm{C}$ oké ga ik dat proberen okay, I'm going to try that

The dialogue is characterized by a very strict alternation of directions given by the agent and feedback given by the client. Most of the directions end in a raising tone, which functions as a turn allocation. The client's feedback has typically the form of repeating the instructions in a soft voice (indicated by ${ }^{\circ} \ldots{ }^{\circ}$ ) and they end with an explicit turn allocation $\uparrow j a$ (yes) with a raising voice. This pattern of directions and feedback make the dialogue to a typical chunked step-by-step procedural instruction, com- parable with the 'streamlined step' instructions that are typical for written procedural discourse [8].

This typical pattern shows how both participants are closely collaborating to make the conversation successful, i.e. to achieve the common goal of completing the task correctly.

\section{How agents instruct}

Chunking. By dividing the procedure in small steps, the agent enables the client to follow the directions immediately, without imposing too much burden for remembering. In other words: agents facilitate the 'switching' between listening to the instruction and performing the actions; the turn allocations function as a signal to move from listening to acting.

Most of the steps include only one action, which enables a very strict control over the switching behavior. Sometimes, however, two or more steps are given without an interruption, as in line 3 of fragment 4 . However, in those cases there is often a short pause that still identifies the single units.

\section{Fragment 4}

1 A Mag u gaan naar menu financieel you may go to menu financial

$2(0,5)$

3 A dan boeken (.) bijwerken boeken than books (.) update books

2 C Even kijken ja:: $\uparrow$ (.) ja:: let me see yes yes

Fragment 5, taken from a call (in English) with a client who has problems with the programmable remote control of his TV, shows two examples of chunks that contain more that one action.

\section{Fragment 5}

1 A could you point to the television?

2 (1.8)

3 A can you point to the television [please?

$4 \mathrm{C} \quad$ [>yeah<

5 A okay, now point to the television, press once the TV button

$6 \quad(1.1)$

7 C >yeah<

8 A once the magic button

9 (1.5)

10 A three six three and hold the last three a little longer.

Two actions are mentioned in line 5 , but since the first is a repetition of a previous instruction, it is understandable that the agent is not waiting for the client's feedback here. The second example of multiple actions is found in 
line 10 , which actually combines four actions: press 3 ; press 6; press 3; hold the last three a little longer. It makes sense to combine the first three actions into one 'chunk' here, since 3-6-3 form the code that has to be inserted. So the three actions can easily be conceptualized (and remembered) as one. Since the fourth action (hold the last three a little longer) has to be carried out simultaneously with the previous one (press 3 ), it has to be uttered in the same breath to prevent the client from releasing the button too soon.

Imperatives and modal verbs. Unlike conventional written instructions, directions in telephone calls are generally not formulated as imperatives. The agent in fragment 3 often uses the model verbal expression mag $u$ (you may), which can be interpreted as a form of negative politeness (suggesting that you are not imposing on the hearer, cf. [9]). If the modal verb is lacking, the action verb is often omitted as well (see line $3,5,7,9$ ), which is possible because the instruction refer to the same type of actions (click). 1 to 9 form a series, the end of which is, among others, indicated by then in line 9 .

The occurrence of the action verb doen (do) and the modal verb mag (may) in line 11 of fragment 3 mark this line as a special step in the procedure. The preceding steps seem to serve as a run-up or a routine procedure to the really important steps that follow. This suggests that the modal verbs (like may) are typically markers of the start of an instructional chain. This explains also the use of the modal verb in line 11 and 18, after interruptions of the instructional chain in line 13 and 16 respectively.

Metaphors for human-computer interaction. It strikes that different action verbs are used in line 1, 11, 14,18 and 20 of fragment 3 . This variety of action verbs seems to indicate a variety of perspectives on the interaction of the client with the computer program.

The verb go to as used in line 1 seems to be the usual verb to indicate menu operations, and it marks a spatial perspective. The user is instructed to 'follow a route' through the program. The verb click, however, refers to the physical aspect of the actions; it describes what the user does with the mouse. The same holds for put in in line 22, which refers to typing on the keyboard. The verb choose in line 20, however, refers to a mental action (decision) made by the user.

Our material includes even more types of action descriptions, for instance:

- ... well, you get a number of bookings before you, and you may just mark everything ...

- ... and then you have to give an OK and than that little window disappears again and than you can just continue ...

- ... and then you say diary ninety new ...
The choice of action verbs is probably related to the agent's perception of the client's level of expertise. Kraan suggests that agents use the agent trajectory model (where computer use is perceived as moving through a space) or the personification model (where the computer is perceived as a human agent) for relatively highexpertise users, while they use the direct inter-face model (where computer use is perceived as a sequence of keystrokes and mouse clicks) for relatively low-expertise users [10]. One of the advantages of the spatial metaphor is its scalability; the route to a particular function or menu can be given in more or less detail, depending on the needs of the user. Line 1 in fragment 6 shows how an agent uses this metaphor to verify whether a client knows 'where' to find a particular function.

\section{Fragment 6}

$1 \mathrm{~A} u$ mag beginnen met een consistentiecontrole $\mathrm{u}$ weet waar die zit?

you may start with a consistency check, you know where that is?

2 C ehh:: ja ik ga eerst deze even sluiten he? dan:: e::ve $(3,0)$ hij zat $(0,5)$ oh nee deze $(1,0)$ je moet altijd ergens kijken waar je het niet verwacht

ehh, yes I am going to close this first right? Then ehh, it was, oh no, this one, you have always to look where you don't expect it.

$3(1,0)$

4 A $\mathrm{mm} \downarrow$

$5 \mathrm{C}$ controle consistentiecontrole ja $\uparrow(1,0)$ hij is al bezig check consistency check, yes, it is busy.

Referential installments, overspecified expressions and verifications. A remarkable deviation from the normal pattern in fragment 3 is found in line 13, where the standard sequence of direction-feedback is interrupted by a statement about what should be visible on the screen at that moment: en dan ziet $u$ een aantal tabbladen en het derde is nummer:: (and then you see a number of tab pages and the third is number). A similar interruption occurs in line 16: dan zult u zien dat boekingen 2004 op vier nul nul nul een $\uparrow$ staat (than you will see that entry 2004 counts four zero zero zero).

These preparatory assertions localize the object of the next action (click), and they are called 'referential installments'. The speaker first installs the referent, and continues the utterance only after a sign of understanding. By doing so, the speaker anticipates on a possible non- or misunderstanding and invites the hearer to give evidence of understanding [11]. Often, but not always, clients react on a referential installment by an acknowledgement, indicating that they really see what the agent means (line 17 of fragment 3 ). 
If the referential installment is not followed by an affirmation by the client, nor by a pause or another affordance of such an affirmation by the agent, it may also been interpreted otherwise, namely as an overspecified expression. An example if this is found in fragment 3 line 13. The tab is not indicated by a simple noun (e.g. 'click on number'), but it is specified with more attributes (it's the third tab page) than strictly required to identify it. Such overspecified expressions are common in written instructions, in particular if the writer expects misunderstandings or ambiguities [12].

Both referential installments and overspecified expressions are means by which the agent tries to prevent misunderstandings about the fields, buttons, or other objects she is referring to. An even more explicit way to prevent such misunderstanding is asking a question which explicitly invites the client to confirm that he understands what the agent means. The question in line 1 of fragment $6(u$ weet waar die zit/you know where it is?) is a good example.

Other verification requests seem not primarily used to focus the users attention on the right object, but to check whether a series of actions have lead to the expected result. An example of this can be found in line 4 of fragment 7. It is not unusual if the client answers not only with yes or no, but elaborates by giving more details about what happens, as can be seen in line 5 .

\section{Fragment 7}

1 A da's snel klaar als het goed is want er is nog niet zoveel te controleren $\uparrow$

that will be finished quickly, because there's not yet so much to check

$2 \mathrm{C}$ nee $\downarrow$ nou ik zie niet dat ie wat doet no, I don't see that it does something

$3 \quad(0,5)$

4 A u heeft nu een uh:: wit groot wit vlak voor $\mathrm{u}$ ? you see a ehh large white surface in front of you?

$5 \mathrm{C}$ ja en er staat eh dus uh boven consistentiecontrole debiteuren crediteuren grootboek (.) nou ja met dat verhaaltje eronder he van mutaties balans dan zie ik een selectie te controleren onderdelen debiteuren crediteuren

yes, and above it is says consistency check debts, creditors, register, with that story under it ehh on transactions balance, that I see selection of parts to check, debtors, creditors

\section{How clients provide feedback}

The repeat of the directions by the hearer functions also as a form of grounding [11]. It provides positive evidence that the agent's utterance is correctly heard and understood. Participants of any conversation continuously seek and give this kind of evidence to ensure that they understand each other correctly. Typical forms of grounding are acknowledgements (minimal approvals such as $\mathrm{mmm}$, yeah), continuers (affordances to continue), continuing attention, and above all: the initiation of the preferred next turn (e.g. answering the question, or rejecting the gratitude expressed by the other).

In face-to-face conversation, the preferred next turn after a direction is non-verbal, namely the clients actions. These actions can be observed by the instructor and provides evidence for correct understanding or misunderstanding. The lack of visual presence in a telephone conversation requires extra conversational effort by the hearer (the client) to give this evidence, and this explains the frequent repetitions of the instructions in the client's feedback.

However, the repeating of the instructions by the caller seems to serve another purpose as well. It also verbalizes what the client is doing at his computer. It is a kind of thinking aloud that goes beyond just verifying the correct interpretation of the agent's directions. By thinking aloud, clients (1) allocate time for themselves to perform the actions (preventing the agent to continue with the next step too early), and (2) inform the agent about what they are doing - which cannot been seen by the agent. So the verbalization replaces the non-verbal visible action which would have the same functions in a face to face situation.

\section{How agents react on missing feedback}

Fragment 8 shows how important the client's feedback is for a successful and smooth conversation. The fragment (original in English) comes from a help call about a programmable universal remote control for audiovisual equipment. The client did not succeed in programming the device correctly; he did not get Teletext on the television screen

\section{Fragment 8}

1 A could you point to the television?

2 (1.8)

3 A can you point to the television [please?

$4 \mathrm{C} \quad$ [>yeah<

5 A okay, now point to the television, press once the TV button

$6 \quad(1.1)$

7 C >yeah<

8 A once the magic button

9 (1.5)

10 A three six three and hold the last three a little longer.

11 (4.9)

12 A did you do it now?

$13 \mathrm{C}>$ yeah<

14 A and does it bring you teletext on the screen?

15 (1.4) 
$16 \mathrm{C}$ no

17 A did you try'n it out? (0.7)

$18 \mathrm{C}$ yes $[$ yes ()

19 A [are you near your television?

$20 \mathrm{C}$ yes yes in front of it

21 A okay try it again, once TV, just once the magic button

$22 \quad(0.6)$

$23 \mathrm{~A}$ and then, three six three.

$24 \quad$ (5.8)

25 A there's no teletext on it?

$26 \mathrm{C}$ no

27 A okay, one moment

The first problem in this fragment occurs already in line 2 , where the client does not respond to the instruction in line 1 . The 1.8 seconds pause brings the agent to a conversational repair in the form of a repeat of the question, with a little bit more imposing formulation (can instead of could, and please added). This evokes the expected feedback (yeah), after which the procedure starts.

The conventional feedback remains undone again after line 8 and after line 10 , which forces the agent to a second repair. The agent's first interpretation of the long pause seems to be that the client did not actually comply with the instructions. After the client's affirmation (line 13), the agent suggests another explanation of the pause: the client did not report that Teletext appeared on the screen (which would have been the solution of the problem). After the client's denial in line 16 , the agent returns to the first explanation: the client has not followed the directions correctly (line 17 and 19). But this is denied again in line 18 and 20 . Then the agent decides to start the whole procedure again, which indeed makes sense only under the assumption that the client did not exactly what the agent commanded.

All-in-all fragment 8 shows that if a client does not provide the conventional feedback, the caller may at least doubt whether the client followed the instruction correctly. This interpretation of the failure seems more probable to the agent than the possibility that she offered the wrong procedure (which was actually the case here!).

There is an interesting phenomenon in line 21-23 of fragment 8 , when the procedural instruction is repeated by the agent. It strikes that the procedural steps are presented in a more 'condensed' way than in line 5-10. Some steps are merged into one conversational turn (line 21), and the pause that offers the client an opportunity for feedback is relatively short (line 22). The action verbs are omitted now and the addition hold the last three a little longer is left out.

It is not unusual to 'condense' instructions if they have already presented before. Within the minimalist framework fading is advocated as an important training strat- egy. If first time learners are confronted with a particular procedure, it should be given in detail, but every time the same procedure reoccurs, it should be given in more general terms [13]. Fading has also been detected in thinking aloud protocols of students who were learning to use a spreadsheet program. The more often they had to repeat a particular procedure, the less actions of this procedure were verbalized in the protocols (with some meaningful exceptions) [14]. And Kraan [10] argues that agents in helpdesk conversation scale their instructions, depending on the level of expertise of the callers.

All in all, it seems naturally to fade procedures if they are repeated. This can be explained as an application of Grice's maxime of relevance: known information does not need to be repeated in detail. However, it can be questioned whether fading is an effective strategy in this particular situation of fragment 8 . If the conventional stepby-step instruction approach failed, it would probably make more sense to use an even more 'controlled' mode of interaction, for instance by evoking more explicit feedback after each step (e.g. by asking yes?, okay? you got that?) to get evidence for correct understanding and compliance with the instructions.

\section{Conclusions}

Agents and clients cooperate in a complex and ingenious manner to achieve their common goals: understanding and solving the client's problem. The analysis of conversational patterns in such calls reveals a number of functional strategies to do this job as effectively and efficiently as possible.

The problem defining phase of the conversation shows a clear 'funnel approach'. Clients start with a narrative that includes many details of which it is not yet clear that they will be needed for the diagnosis and the solution of the problem. Especially clients with low expertise do not know in advance what might be relevant and what is not. So what they do is 'firing a shower of shots', hoping that one of them will hit the target. Seemingly irrelevant details may become useful for agents, because there may be many possible causes of the problem, and some of these might be unexpected or even unique. The client's information in fragment 1 about cleaning the keyboard triggered the later diagnosis of the problem. Had the agent followed a 'normal' heuristic, then it might have been quite unlikely that she discovered the true cause of the problem.

The broad scope of the client's narrative is subsequently narrowed by interrogation and simulation, where agents follow heuristics that might help them with diagnosing the problem. We were not yet able to study these interrogations in detail, to find out which approaches are successful and which might be less successful. However, 
research on diagnostic behavior can serve as background for a more detailed study of this process.

It is striking that both the actual diagnosis and the announcement of the solution are often absent in our data. These elements can be regarded as extra coordinating information that helps the client to understand what went wrong and what he is going to do about it. Skipping there steps might be explained by the strive for efficiency by both the agent and the client. They want to have the job done as quick as possible, and they don't want to waste time with explanations. More generally, the conversation is not framed as a learning process by any of the parties, but as an incidental help encounter [15].

However, coordinating information about the problem and the solution might be important for several reasons. Firstly, since both the agent's summary of the diagnosis and her preview of the solution do sometimes elicit a discussion (negotiation), which may lead to reconsidering and perhaps changing the diagnosis or the solution. Moreover, coordinating information helps clients to understand what they are doing. This might help them not only to solve the problem better, but also to learn from the helpdesk call, so that they can better proceed if the same problem or a similar problem occurs in the future. Research on written instructions has learned that coordinating information seems to affect the performance of users [16] as well as their confidence in their own abilities [17]. Of course, there is a difference between written instructions and the interactive coaching approach in a helpdesk call, but it makes sense to assume that similar effects will occur in interactive instructional discourse.

The patterns we found in the instructional phase of help desk calls show how participants work closely together. Many of the observed phenomena relate to the use of the telephone, which allows an exchange of verbal information, but also requires many forms of compensation for the lack of visual presence. The most obvious men to do this are careful chunking of the procedure, referential installments and verification requests by the agent, "think aloud' by the client, and very explicit completions of conversational turns by both parties. All these contribute to a carefully controlled exchange of information that enables the participants to adjust instructions and actions as precisely as possible. It is meaningful that complicated repairs are needed if one of the parties does not contribute adequately to this strict control, as is shown by the analysis of fragment 8 .

Although practical applications were not the fist objective of this study, this analysis of helpdesk calls may have some. Firstly, the findings can play a role in the training of helpdesk agents. Most of the training programs focus on technical issues (knowledge of diagnostic procedures and using information systems to find the right solution), on affective aspects such as friendliness and politeness (make sure you use the clients name at least three times during the call, don't react on grumbling, express your appreciation for the call), and on company policies (mention the companies name, promote other products). The typical 'coaching' behavior found in this study is not a paramount issue in such training programs. Confronting trainees with a demonstration of well chosen examples of real helpdesk conversations (both successful and unsuccessful) might at least make them aware of effective and ineffective strategies.

Another application of helpdesk call analysis might lie in the design of other forms of user support, especially online help. For instance, the pattern of problem telling in helpdesk calls is completely different from the usual way users have to access online help, namely by inserting or selecting keywords. Research has shown that keyword search is ineffective in no more than $50 \%$ of the cases [18]. Our insight in the typical narrative structures users apply to describe their problems to an helpdesk agent, might help to develop 'wizards' that can be more effective for finding solutions in online help.

Finally, our analysis of helpdesk calls forms an interesting and potentially useful extension of our understanding of instructive communication as such. There are many studies related to the effectiveness of written procedural instructions. Our analysis shows many similarities (such as switching, chunking, referential installments and overspecifications), but also differences, such as interactive verifications. Understanding technical instructions and the determinants of their effectiveness is an important challenge for linguist and (other) communication specialist, given the tsunami of new technologies in our everyday life, making us all to non-experts in many ways.

\section{References}

[1] J. Downing, "Using Customer Contact Center Technicians to Measure the Effectiveness of Online Help Systems," Technical Communication, vol. 54, pp. 201-209, 2007.

[2] L. S. Van Velsen, M. F. Steehouder, and M. D. T. De Jong, "Evaluation of User Support. Factors that Affect User Satisfaction with Helpdesks and Helplines," IEEE Transactions on Professional Communication, 2007 (in press).

[3] R. M. Frankel, " "I wz Wondering - uhm Could Raid uhm Effect the Brain Permanently d'y Know?": Some Observations on the Intersection of Speaking and Writing in Calls to a Poison Control Center," Western Journal of Speech Communication vol. 53, pp. 195-226, 1989.

[4] H. Houtkoop, F. Jansen, and A. Walstock, "Collaborative Problem Description in Help Desk Calls," in Calling for Help. Language and Social Interaction 
in Telephone Helplines, C. D. Baker, M. Emmison, and A. Firth, Eds. Amsterdam/Philadelphia: John Benjamins., 2005, pp. 63-89.

[5] E. Smit, Okay, Nou Dat Was mijn Vraag Meneer (Okay, well That was my Question, Sir), MSc Thesis, University of Twente, 2004.

[6] C. Baker, M. Emmison, and A. Firth, "Discovering Order in Opening Sequences: Calls to a Software Helpline," in How to Analyse Talk in Institutional Settings, A. McHoul and M. Rapley, Eds. London / New York: Continuum, 2001, pp. 41-56.

[7] C. D. Baker, M. Emmison, and A. Firth, "Calibrating for Competence in Calls to Technical Support.", in Calling for Help. Language and Social Interaction in Telephone Helplines, C. D. Baker, M. Emmison, and A. Firth, Eds. Amsterdam/Philadelphia: John Benjamins, 2005, pp. 39-62.

[8] D. K. Farkas, "The Logical and Rhetorical Construction of Procedural Discourse," Technical Communication, vol. 46, pp. 42-54, 1999.

[9] P. Brown and S. C. Levinson, Politeness: Some universals in language usage. Cambridge MS: Cambridge University Press, 1987.

[10] I. Kraan, "The Metaphoric Use of Space in ExpertLay Interaction about Computing Systems," in Calling for Help. Language and Social Interaction in Telephone Helplines, C. D. Baker, M. Emmison, and A. Firth, Eds. Amsterdam/Philadelphia: John Benjamins, 2005, pp. 91-105.

[11] H. H. Clark and S. E. Brennan, "Grounding in Communication," in Perspectives on Socially Shared Cognition, J. Levine, L. B. Resnick, and S. D. Teasley, Eds. Washington, DC: APA Books, 1991, pp. 127-149.

[12] A. Maes, A. Arts, and L. Noordman, "Reference Management in Instructive Discourse," Discourse Processes, vol. 37, pp. 117-144, 2004.

[13] H. Van der Meij and J. Carroll, "Principles and Heuristics for Designing Minimalist Instruction," in Minimalism beyond the Nurnberg Funnel, J. M. Carroll, Ed. Cambridge MS: MT Press, 1998, pp. 1953.

[14] H. Glasbeek, "Ik Doe wel wat hier Staat, maar hij niet." Een Onderzoek naar Vaardigheidverwerving door Gebruikers van Leshandleidingen bij een Computerprogramma ("I do what it Says, but it does not. A study into Skill Acquisition by Users of Software Tutorials"). $\mathrm{PhD}$. Thesis, Utrecht University, 2001.

[15] M. Steehouder and D. Hartman, "How Can I Help You? User Instructions in Telephone Calls," presented at IPCC 2003: The shape of knowledge, Orlando FL., 2003.
[16] P. Dixon, "The structure of Mental Plans for Following Directions," Joumal of Experimental Psychology, vol. 13, pp. 18-26, 1987.

[17] N. Loorbach, M. Steehouder, and E. Taal, "The Effects of Motivational Elements in User Instructions," Journal of Business and Technical Communication, vol. 20, pp. 177-199, 2006.

[18] M. Steehouder, "The Quality of Access: Helping Users Find Information in Documentation," in Quality of Technical Documentation, M. Steehouder, C. Jansen, P. Poort van der, and R. Verheijen, Eds. Amsterdam: Rodopi, 1994.

\section{Appendix: transcription codes}

\begin{tabular}{|c|c|}
\hline \multicolumn{2}{|c|}{$\begin{array}{l}31 \quad \text { line number } \\
\text { A, C Agent, Client (caller) } \\
(.) \quad \text { pause shorter than } 0.3 \text { seconds } \\
(1,5) \text { pause in seconds }\end{array}$} \\
\hline 0 & questioning tone at the end of an utter- \\
\hline & \\
\hline $\begin{array}{l}\text { [word } \\
\text { ultaneously }\end{array}$ & Utterances of two speakers spoken si- \\
\hline wo:rd & prolongation of vowel or cor \\
\hline & \\
\hline WORD & spoken aloud \\
\hline word spo & vith emphasis \\
\hline & spoken silently \\
\hline$>$ word $<$ & fast \\
\hline
\end{tabular}

\section{About the author}

Michaël Steehouder is full professor of Technical Communication at the University of Twente, The Netherlands. He leads a team of researchers with interest in document design and user support. His publications include several textbooks on communication skills, forms design, software manuals, and over 150 articles, conference papers, and book chapters, including over 35 in English. He is member of IEEE-PCS's Administrative Committee and associate editor of IEEE Transactions in Professional Communications. 